\title{
Seed weight and germination time affect growth of 2 shrubs
}

\author{
JUNQIANG HOU AND J.T. ROMO
}

Authors are post-doctoral fellow and professor, Dept. of Plant Sciences, Univ. of Saskatchewan, 51 Campus Drive, Saskatoon, Sask. S7N 5A8.

\begin{abstract}
The objective of this study was to investigate relationships between seed size, time of germination, and seedling growth in winterfat (Ceratoides lanata (Pursh) J. T. Howell) and silver sagebrush (Artemisia cana Pursh). Individual seeds of winterfat were placed into 6 weight classes ranging from $1.5-2.0$ to $>4.0 \mathrm{mg}$ seed $^{-1}$ while silver sagebrush seeds were separated into 7 classes ranging from 0.53 to $0.83 \mathrm{mg} \mathrm{seed}^{-1}$. Seeds were incuhated at $18^{\circ} \mathrm{C}$, seedlings with radicles $<3.0 \mathrm{~mm}$ were removed at $1,2,3$, 4-5 and 6-12 day intervals, grown 5 days in darkness at $18^{\circ} \mathrm{C}$, and axial length measured. Total germination of winterfat increased $5.5 \% \mathrm{mg}^{-1}$ increase in seed weight, but germination rate was similar among weight classes, averaging $53.1 \%$ day $^{-1}$. Seed weight and time of germination interactively influenced growth of winterfat seedlings. Seedling length of winterfat was more than 2-fold greater in the $>4.0$ than the $1.5-2.0 \mathrm{mg} \mathrm{seed}^{-1}$ class while lengths of seedlings in the $>2.0-2.5$ through $>3.5$ to $4.0 \mathrm{mg} \mathrm{seed}^{-1}$ weight classes were intermediate. Seedling length decreased 0.9 to $3.3 \mathrm{~mm}$ for each day that germination was delayed from 1 to 12 days with the least and greatest reductions occurring for lightest and medium weight seeds, respectively. Total germination for silver sagebrush initially increased with seed weight, but declined at weights greater than about $0.57 \mathrm{mg}$ seed $^{-1}$; germination rate was similar $\left(57.1 \%\right.$ day $\left.^{-1}\right)$ among weight classes. Seedling length of silver sagebrush increased 0.3 $\mathbf{m m ~} \mathrm{mg}^{-1}$ increase in seed weight whereas length decreased curvilinearly as time to germination was delayed. When winterfat is used for restoration, relatively heavy seeds should be used because they have the greatest germination and produce large seedlings. Because seedling length of silver sagebrush increased with increasing seed weight it is also desirable to select heavier seeds; however, reduced germination in heavier seeds may necessitate increasing seeding rates.
\end{abstract}

Key Words: Artemisia cana Pursh., Ceratoides lanata (Pursh) J. T. Howell, Eurotia lanata (Pursh) Moq., Krascheninnikovia lanata Gueldenstaedt, restoration, seed vigor, seedling vigor, silver sagebrush, winterfat.

Seed size and germination behavior affect early seedling performance (Harper and Obeid 1967, Stanton 1984, Morse and Schmitt 1985, Banovetz and Scheiner 1994). Typically, seed size is positively correlated with seedling vigor (Harper and Obeid

\footnotetext{
Funding for this research provided by research grants to JTR from the CanadaSaskatchewan Agriculture Green Plan, Saskatchewan Agriculture Development Fund, and Ducks Unlimited Canada.

Manuscript accepted 20 Jan 1998
}

1967, Morse and Schmitt 1985). Large and medium size seeds of winterfat (Ceratoides lanata (Pursh) J. T. Howell, syn. Eurotia lanata (Pursh) Moq., syn. Krascheninnikovia lanata Gueldenstaedt) germinate faster and in higher numbers than small seeds (Springfield 1973). Although high seedling vigor may not necessarily translate into superior performance in adult plants (Harper and Obeid 1967), it may enhance seedling survival under natural conditions (Hendrix 1984, Morse and Schmitt 1985).

Total germination and germination rate influence dynamics of seedling populations in natural habitats. Studies have related seed size to total germination and germination rate. For example, within species larger seeds often have greater germination than smaller ones (Hendrix 1984, Morse and Schmitt 1985, Prinzie and Chmielewski 1994, Andersson 1996). Smaller seeds germinate more rapidly than larger seeds in Pastinaca sativa (Hendrix 1984), but a reversed situation occurs in Erodium brachycarpum (Stamp 1990) and Pogogyne abramsii (Zammit and Zedler 1990).

Germination rate has been used as a measure of seed vigor (see Steiner 1990). Seed vigor is, however, not necessarily equivalent to seedling vigor because the former describes seed germination while the latter applies to post-germination growth. The ecological significance of germination rate has been discussed in terms of competitive advantage and risk-spreading (Hendrix 1984, Venable and Brown 1988, Zammit and Zedler 1990). Only 1 reported study was found (Booth and Morgan 1993) that explored effects of germination rate on seedling vigor. Post-germination growth in Artemisia tridentata Nutt., Cercocarpus ledifolius Nutt., and Pinus ponderosa Dougl. was negatively correlated with time-to-germination (later germinating seeds produced slower growing seedlings) while seed germination and seedling growth in Purshia tridentata (Pursh) DC. were positively related.

The objective of this study was to investigate relationships between seed size, germination rate and seedling vigor in winterfat and silver sagebrush (Artemisia cana Pursh.), native shrubs of Northern Mixed Prairie of North America (Coupland 1950). These shrubs were chosen because they are excellent candidate species for ecological restoration, but information on their germination ecology is incomplete. By separating seeds according to weight, possible confounding effects of seed size and germination rate on seedling vigor might be eliminated.

\section{Materials and Methods}

Winterfat diaspores were collected in late September 1995 at the University of Saskatchewan, Matador Research Station $\left(50^{\circ} 42^{\circ} \mathrm{N}, 107^{\circ} 43^{\circ} \mathrm{W}\right.$, elevation $\left.685 \mathrm{~m}\right)$. A description of this site was provided by Romo et al. (1995). Winterfat diaspores 
were dried in the laboratory for about 1 month, and then stored in paper bags at $-15^{\circ} \mathrm{C}$. Before experiments, diaspore bracts were manually removed, and seeds were left at room temperature for 2 months to allow after-ripening (Springfield 1972). Individual seeds were weighed and classified into classes of 1.5-2.0, $>2.0-2.5,>2.5-3.0,>3.0-3.5,>3.5-4.0$, and $>4.0$ mg seed $^{-1}$.

Silver sagebrush seeds (achenes) were collected in late October 1995 near Outlook, Saskatchewan $\left(51^{\circ} 29^{\circ} \mathrm{N}, 107^{\circ} 03^{\circ} \mathrm{W}\right.$, elevation $520 \mathrm{~m}$ ). The collection site was a steep, naturally-revegetated roadcut dominated by silver sagebrush, western wheatgrass (Agropyron smithii Rydb.), and needle-and-thread (Stipa comata Trin. \& Rupr.). These sceds werc dricd in the laboratory for 4 weeks, cleaned by hand, and stored in paper bags at $4^{\circ} \mathrm{C}$ until use. Seeds were separated into 7 classes with a South Dakota seed blower, and weight of 100 seeds was determined from 5 replicates for each class. The 7 weight classes were (mean + SE) 0.53 $\pm 0.014,0.56 \pm 0.012,0.60 \pm 0.011,0.63 \pm 0.007,0.68 \pm 0.007$, $0.74 \pm 0.010$, and $0.83 \pm 0.013 \mathrm{mg} \mathrm{seed}^{-1}$.

Seeds were dusted with Captan (N-[(trichloromethyl)-thio]-4cyclohexene-1,2-dicarboximide) and 4 replicates of 50 seeds for each weight class were imbibed in $100 \times 15 \mathrm{~mm}$ Petri dishes lined with 2 layers of No. 1 Whatman filter paper moistened with $4 \mathrm{ml}$ distilled water. Petri dishes were placed in $32 \times 21 \times 7 \mathrm{~cm}$ plastic germination boxes lined with wet paper towels and incubated at $18^{\circ} \mathrm{C}$ in darkness. At 6 days of incubation, $0.5 \mathrm{ml}$ water was added to each Petri dish. Germination was checked every day for 12 days. Seeds with visible, protruded radicles were considered germinated, and seedlings were transferred to germination boxes lined with 6 layers of germination paper moistened with $120 \mathrm{ml}$ distilled water. A few seedlings had radicles $>3 \mathrm{~mm}$; they were discarded to ensure seedlings were uniform in size. The boxes were placed in an incubator at $18^{\circ} \mathrm{C}$ in darkness, and after 5 days axial length of seedlings was measured by hand to the nearest millimeter.

During experiments with silver sagebrush, relatively low germination of seeds was observed for the heaviest seed class. To test if dormancy was involved in germination, 3 replicates of 40 seeds $\left(0.83, \mathrm{SE}=0.013 \mathrm{mg} \mathrm{seed}^{-1}\right)$ each were imbibed in $0.1 \mathrm{~mm}$ gibberellic acid $\left(\mathrm{GA}_{3}\right)$ and incubated in conditions as described above for 12 days. Seeds that did not germinate were pricked and further imbibed in a $0.5 \%$ solution of tetrazolium chloride for 18 hours to test seed viability (Moore 1962).

Germination rate was calculated from: $\Sigma\left(N_{i} / T_{i}\right) / T G$, where $N_{i}=$ is the number of seeds that germinated on day $i$ after imbibition, $\mathrm{T}_{\mathrm{i}}=$ day $\mathrm{i}$ after imbibition, and $\mathrm{TG}=$ total germination (Evetts and Burnside 1972). A randomized-complete-block design was used for germination tests; an unbalanced randomized-completeblock design was used for tests of seedling length (Snedecor and Cochran 1980). All experiments were repeated. Arcsin transformation was applied to germination data, and all data were subjected to analysis of variance. Since few or no seedlings were obtained in the late germination periods for some seed weight classes, seedling length data were pooled to give 5 levels of timeto-germination effects on seedling growth, i.e. 1, 2, 3, 4-5, and 6- 12 days after imbibition. In regression analyscs the mid-point of seed weight classes or day of germination was used to scale independent variables. An exception to this scaling approach was the use of 4.0 as the mid-point for the class of $>4.0 \mathrm{mg} \mathrm{seed}^{-1}$ in winterfat. Best fit regression equations were selected (Snedecor and Cochran 1980). In all cases statistical significance was assumed at $\mathrm{P} \leq 0.05$.

\section{Results and Discussion}

\section{Germination}

Total germination of winterfat seeds increased $5.5 \% \mathrm{mg}^{-1}$ increase in weight (Fig. 1), but germination rate was not affected by seed weight $(P=0.103)$, averaging $51.3 \%$ day $^{-1}(\mathrm{SE}=0.6)$. Total germination for silver sagebrush initially increased with seed weight, but then declined at weights greater than about 0.57 $\mathrm{mg} \mathrm{seed}^{-1}$ (Fig. 2). Germination rate was similar $(P=0.058)$ among weight classes, averaging $57.1 \%$ day $^{-1}(\mathrm{SE}=1.3)$. These findings agree with Booth and Haferkamp's (1995) assertion that seed size does not have a strong influence on germination rate.

The tetrazolium chloride test indicated $63 \%$ viability of nongerminating seeds in the heaviest class for silver sagebrush, suggesting most seeds were dormant. After treating seeds of the heaviest class with $\mathrm{GA}_{3}$, total germination averaged $56.7 \%(\mathrm{SE}=$ $3.9)$, but was not significantly $(P>0.05)$ different from $49.2 \%$ $(\mathrm{SE}=3.2$ ) germination in control. These results do not prove dormancy contributed to low germination of large silver sagebrush seeds. Failure of $\mathrm{GA}_{3}$ to promote germination does not necessarily rule out existence of dormancy because dormancy mechanisms vary among species, and this chemical is not always effective in breaking it (Simpson 1990). Seed dormancy occurs in some subspecies and populations of big sagebrush (Artemisia tridentata Nutt.) (Meyer and Monsen 1992, Booth et al. 1997, Bai et al. 1997). Although dormancy is more often associated with small than large seeds (Andersson 1996), a higher proportion of dormancy in large than small seeds also exists in Erodium brachycarpum (Stamp 1990) and Coreopsis lanceolata (Banovetz and Scheiner 1994).

\section{Seedling Growth}

Growth of winterfat seedlings was interactively affected by seed size and day of germination. Seedling length was more than 2-fold greater in the $>4.0$ than the $1.5-2.0 \mathrm{mg} \mathrm{seed}^{-1}$ class while lengths of seedlings in the $>2.0-2.5$ through $>3.5-4.0 \mathrm{mg} \mathrm{seed}^{-1}$

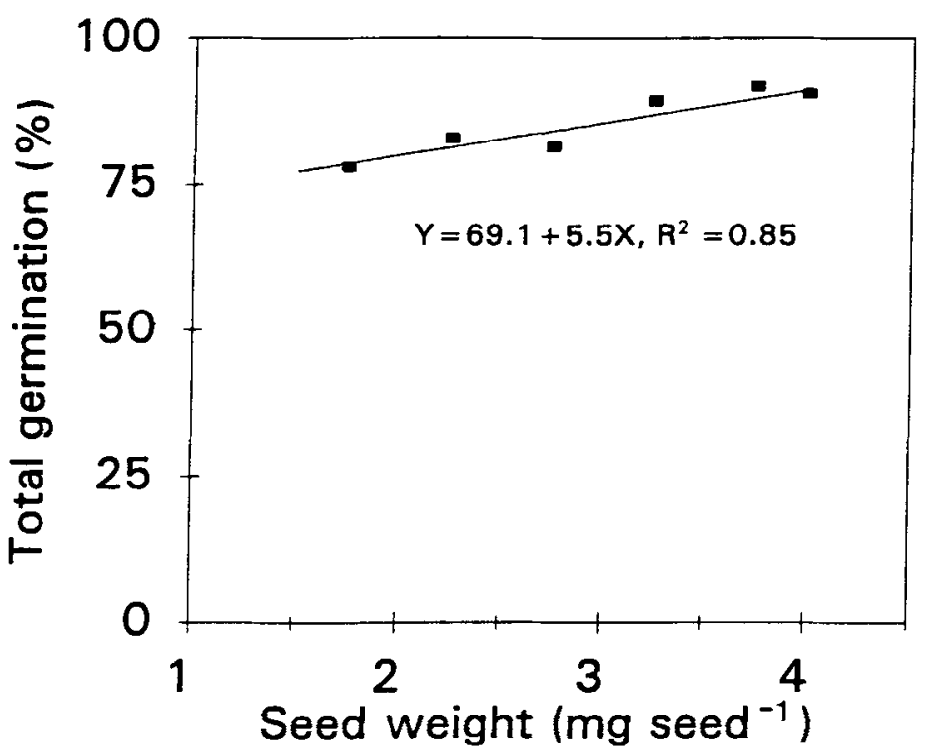

Fig. 1. Predicted regression line for total germination of winterfat seeds with different weights. Seeds were incubated at $18^{\circ} \mathrm{C}$ in darkness for 12 days. Each point is the mean for 8 replicates of $\mathbf{5 0}$ seeds each. 


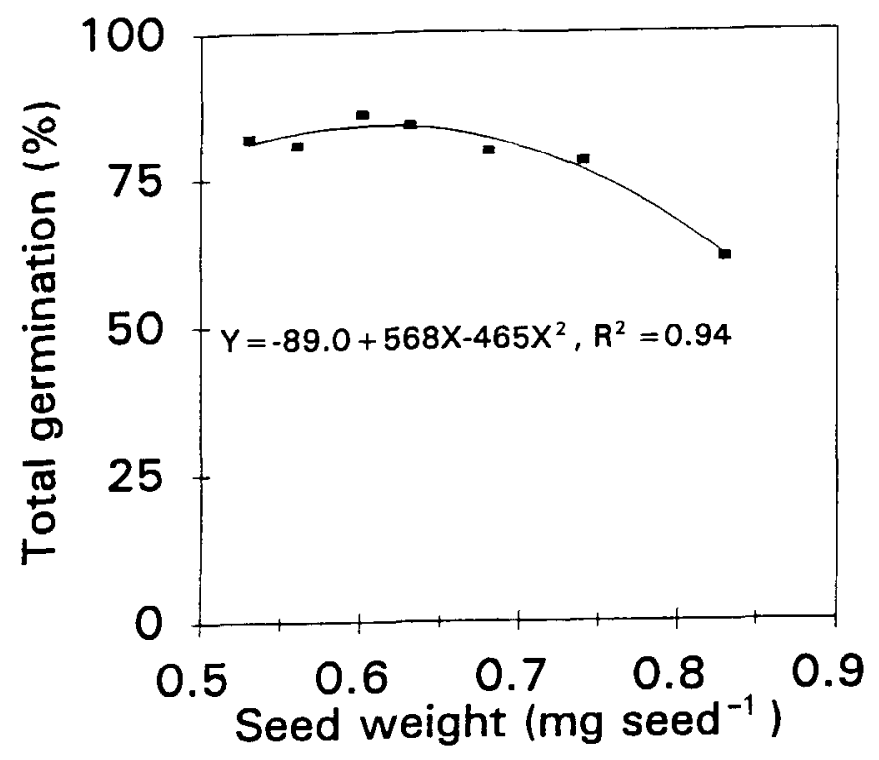

Fig. 2. Predicted regression line for total germination of silver sagebrush seeds with different weights. Seeds were incuhated at $18^{\circ} \mathrm{C}$ in darkness for 12 days. Each point is the mean for 8 replicates of 50 seeds each.

weight classes were intermediate (Table 1, Fig. 3). Seedling length decreased 0.9 to $3.3 \mathrm{~mm}$ for each day that germination was delayed from 1 to 6-12 days with the least and greatest reductions (slopes of regression equations) occurring for lightest and the $>3.0-3.5 \mathrm{mg} \mathrm{seed}^{-1}$ weight classes, respectively. High coefficients of determination within seed weight classes imply growth of seedlings was strongly controlled by time of germination.

Seedling length of silver sagebrush was positively correlated with seed weight and negatively correlated with day of germination. Over the 0.53 to $0.83 \mathrm{mg} \mathrm{seed}^{-1}$ weight range, seedling length increased $34 \mathrm{~mm} \mathrm{mg}^{-1}$ increase in seed weight (Fig. 4). Seedling length decreased curvilinearly as the day of germination

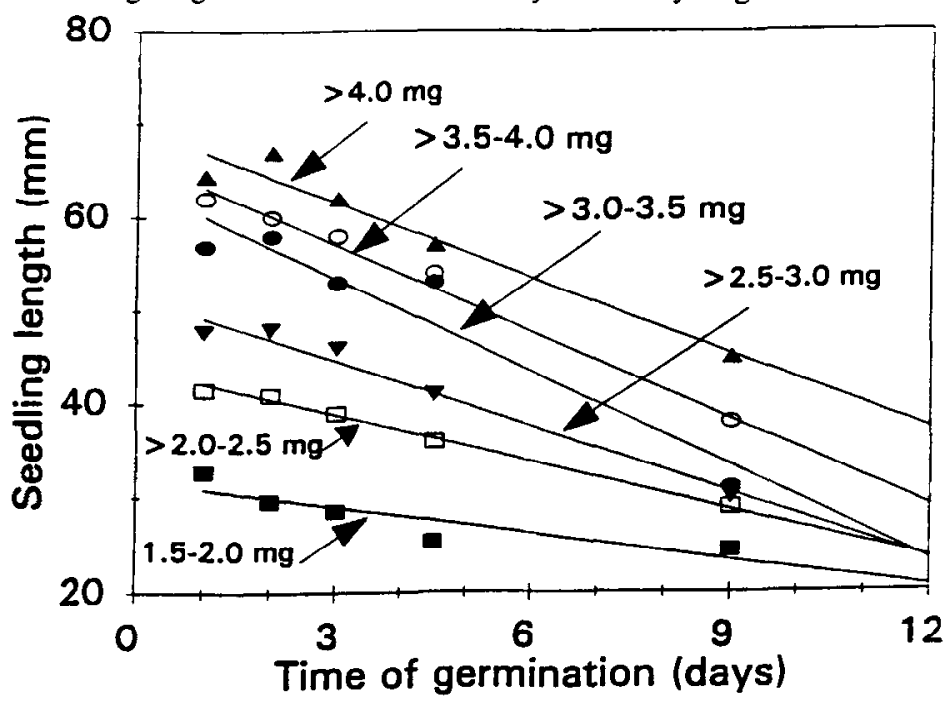

Fig. 3. Predicted regression lines for relationships between time of germination and length of winterfat seedlings for 6 seed weight classes. Each point is the mean length of $13-48$ seedlings. Regression equations are presented in Table 1.
Table 1. Regression equations for relationships between seedling length $(\mathrm{mm})(\mathrm{Y})$ and day of germination $(X)$ for winterfat. Seedlings were grown at $18^{\circ} \mathrm{C}$ in darkness for 5 days.

\begin{tabular}{cccc}
\hline Seed weight & Regression equation & $\mathrm{R}^{2}$ & $\mathrm{P}$ \\
\hline (mg seed $^{-1}$ ) & & & \\
$1.5-2.0$ & $\mathrm{Y}=31.8-0.9 \mathrm{X}$ & 0.71 & 0.047 \\
$>2.0-2.5$ & $\mathrm{Y}=43.9-1.7 \mathrm{X}$ & 0.99 & $<0.001$ \\
$>2.5-3.0$ & $\mathrm{Y}=51.6-2.4 \mathrm{X}$ & 0.97 & 0.001 \\
$>3.0-3.5$ & $\mathrm{Y}=63.4-3.3 \mathrm{X}$ & 0.90 & 0.009 \\
$>3.5-4.0$ & $\mathrm{Y}=66.3-3.1 \mathrm{X}$ & 0.98 & 0.001 \\
$>4.0$ & $\mathrm{Y}=69.6-2.7 \mathrm{X}$ & 0.94 & 0.004 \\
\hline
\end{tabular}

was delayed: seedlings germinating on days 6-12 were about $15 \%$ shorter than those germinating on the first day of incubation (Fig. 5). Seedlings of big sagebrush were also smaller from seeds that germinated later; however, confounding effects of seed size were not isolated (Booth and Morgan 1993). Germination rate and total germination of Wyoming big sagebrush (Artemisia tridentata Nutt. ssp. wyomingensis) were also greater in seed lots with heavier secd weights (Bai et al. 1997).

Large seeds often have greater emergence from deep burial than small seeds and produce larger seedlings (Harper and Obeid 1967, Curtis and McKersie 1984, Morse and Schmitt 1985, Banovetz and Scheiner 1994). In agreement with these observations, the present study demonstrated positive relationships between seed weight and seedling size in winterfat and silver sagebrush. Under natural conditions winterfat and Artemisia species usually germinate on the soil surface or at shallow depths in the ficld (Booth 1989, Young and Evans 1989), but during artificial seeding they are often buried. Fast growing seedlings may have the advantage of rooting in the soil where water (Waddington and Shoop 1995) and mineral supplies are more reliable. Seedling establishment may therefore be superior for large than small seeds (see Booth and Haferkamp 1995).

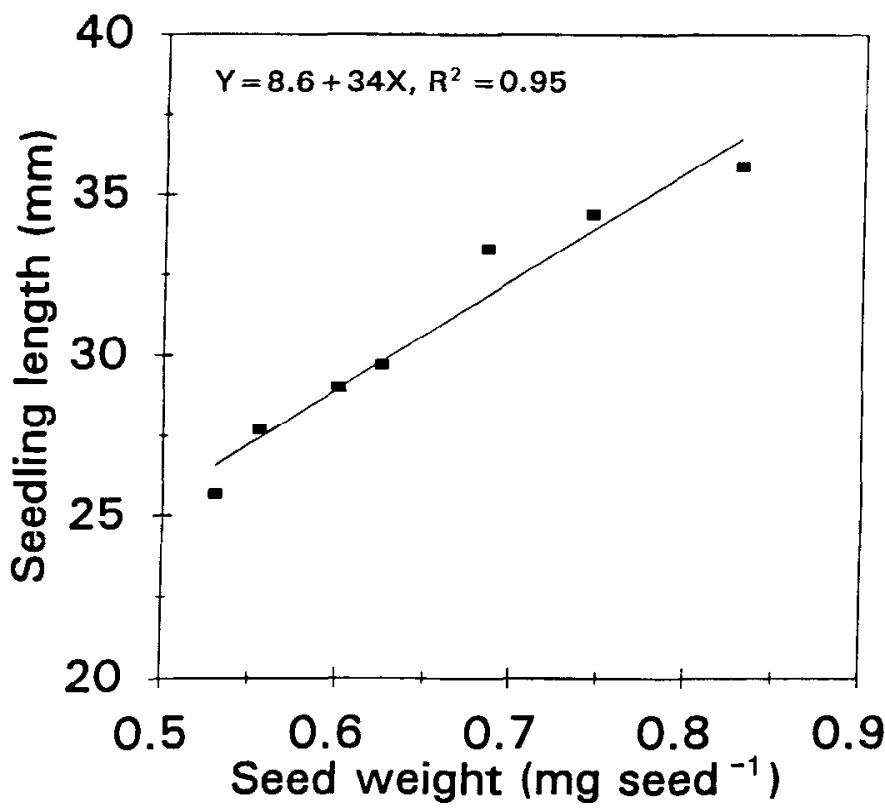

Fig. 4. Predicted regression line for seedling length in different seed weights of silver sagebrush. Each point is the mean of 141-317 seedlings. 


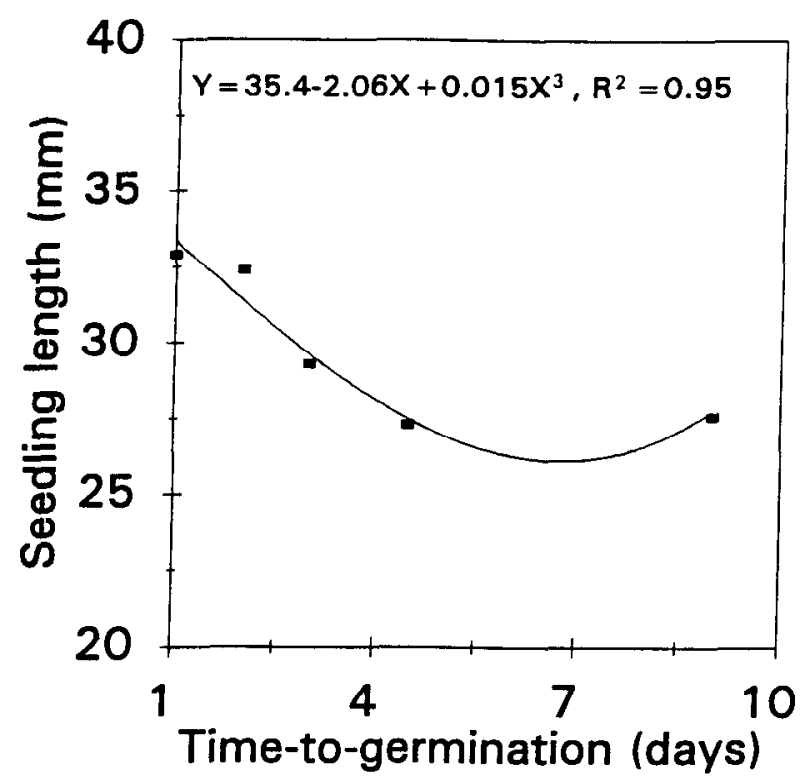

Fig. 5. Predicted regression line for seedling length for different times of germination of silver sagebrush seeds. Each point is the mean of 141-317 seedlings.

Early seedling growth is largely supported by seed reserves (Harper et al. 1970, Curtis and McKersic 1984). Loss of reserves from seeds during imbibition may have also decreased seedling growth in late-germinating seeds; mineral losses also occur in hydrated seeds (Senaratna and McKersie 1983, Ptasznik and Khan 1993, Debaene-Gill et al. 1994). Winterfat and silver sagebrush seeds are relatively small with large surface to volume ratios, and may be particularly prone to leakage losses. Seed reserves available for seedling growth can also be reduced through respiratory consumption before germination (Hilton and Owen 1985, Adkins et al. 1988). Winterfat seeds have a relatively small perisperm (Booth 1988), and sagebrush seeds have only residual endosperm (Booth and Morgan 1993). On the other hand, Curtis and McKersie (1984) indicated that reduced sink size (axis) in small seeds, rather than supply of nutrients, was responsible for limited seedling growth. The present study compared effects of germination rate on seedling growth within seed weight classes, and the initial axis size should have been similar. Axes of late germinating seeds may, however, have weak growth potentials, and be unable to transport and use reserves efficiently.

In summary, establishment of winterfat and silver sagebrush is likely influenced by seed size and time of germination since both affected vigor of seedlings. Seedlings from early germinating seeds can gain a competitive advantage in plant communities (Hendrix 1984). They also capture the earliest opportunity for seedling establishment in a growing season, though this is probably a trade-off of risk-spreading (Venable and Brown 1988, Zammit and Zedler 1990). This study and that of Booth and Morgan (1993) indicate that early germinating seeds may also have greater survival because they produce more vigorous seedlings than late germinating seeds. This conclusion is at least partially supported by the fact that survival in the field was greatest for winterfat seedlings emerging in May and poorer for those emerging in June, July, or August (Labek and Romo unpub. data). Late emerging seedlings of winterfat also established poor- ly under drought stress compared to seedlings emerging early (Waddington and Shoop 1995), and seedlings of winterfat from early germinating seeds are more desiccation tolerant than those germinating later (Hou et al. 1999). Early emergence is also advantageous for silver sagebrush because early emerging seedlings are more tolerant of freezing temperatures than later emerging ones (Hou and Romo 1998).

When winterfat is used for restoration, relatively heavy seeds should be used for they are expected to have the greatest germination and produce large seedlings. Since winterfat seedlings are more vigorous and germination is greater for heavier than lighter seeds, it may be possible to reduce seeding rates. That seedling growth of silver sagebrush increased with increasing seed weight suggests it may also be desirable select heavier seeds. Reduced germination in heavier seeds of silver sagebrush may necessitate increased seeding rates.

\section{Literature Cited}

Adkins, S. W., S. J. Symons, and G. M. Simpson. 1988. The physiological basis of seed dormancy in Avena fatua. VIII. Action of malonic acid. Physiol. Plant. 72:477-482.

Andersson, S. 1996. Seed size as a determinant of germination rate in Crepis tectorum (Asteraceae): Evidence from a seed burial experiment. Can. J. Bot. 74:568-572.

Bai, Y, D.T. Booth, and E.E. Roos. 1997. Effects of seed moisture on Wyoming big sagebrush seed quality. J. Range Manage. 50:419-422.

Banovetz, S. J. and S. M. Schciner. 1994. The effects of seed mass on the seed ecology of Coreopsis lanceolata. Amer. Midl. Natur. 131:65-74.

Booth, D. T. 1988. Winterfat diaspore morphology. J. Range Manage. 41:351-353.

Booth, D.T. 1989. A model of freeze tolerance in winterfat germinants, p. 83-89. In: A. Wallace, E.D. McArthur, and M.R. Haferkamp (eds.), Proc. Symp. on shrub ecophysiology and biotechnology. USDA For. Serv. Gen. Tech. Rep. INT-256.

Booth, D.T. and M.R. Haferkamp. 1995. Morphology and seedling establishment, p. 239-290. In: D.J. Bedunah and R.E. Sosebee (eds.), Wildland plants-Physiological ecology and developmental morphology. Soc. for Range Manage. Denver, Colo.

Booth, D. T. and D. R. Morgan. 1993. Post-germination growth related to time-to-germination for four woody plants. J. Seed Tech. 16:30-38.

Booth, D.T., Y. Bai, and E.E. Roos. 1997. Preparing sagebrush seed for market: Effects of debearder processing. J. Range Manage. 50:51-54.

Coupland, R. T. 1950. Ecology of Mixed Prairie in Canada. Ecol. Monogr. 20:271-315.

Curtis, K. and B. D. McKersie. 1984. Growth potential of axis as determinant of seedling vigor in birdsfoot trefoil. Crop Sci. 24:47-50.

Debaene-Gill, S. B., P. S. Allen, and B. W. Donald. 1994. Dehydration of germinating perennial ryegrass seeds can alter rate of subsequent radicle emergence. J. Exp. Bot. 45:1301-1307.

Evetts, L.L. and O.C. Burnside. 1972. Germination and seedling development of common milkweed and other species. Weed Sci. 20:371-378.

Harper, J. L., P. H. Lovell, and K. G. Moore. 1970. The shapes and sizes of seeds. Ann. Rev. Ecol. Syst. 1:327-356.

Harper, J. L. and M. Obeid. 1967. Influence of seed size and depth of sowing on the establishment and growth of varieties of fiber and oil seed flax. Crop Sci. 7:527-532.

Hendrix, S. D. 1984. Variation in seed weight and its effects on germination in Pastinaca sativa L. (Umbelliferae). Amer. J. Bot. 71:795-802.

Hilton, J. R. and P. D. Owen. 1985. Light and dry storage influences on the respiration of germinating seeds of five species. New Phytol. 99:523-531. 
Hou, J. and J.T. Romo. 1998. Cold-hardiness of silver sagebrush seedlings. J. Range Manage. 51:704-708.

Hou, J. Q., J. T. Romo, Y. G. Bai, and D. T. Booth. 1999. Desiccation tolerance in seeds and seedlings of winterfat seedlings. J. Range Manage. 52:In press.

Meyer, S. E. and S. B. Monsen. 1992. Big sagebrush germination patterns: Subspecies and population differences. J. Range Manage. 45:87-93.

Moore, K. P. 1962. Tetrazolium as a universally acceptable quality test of viable seed. Proc. Seed Testing Assoc. 27:795-805.

Morse, D. H. and J. Schmitt. 1985. Propagule size, dispersal ability, and seedling performance in Asclepias syriaca. Oecologia 67:372-379.

Prinzie, T. P. and J. G. Chmielewski. 1994. Significance of achene characteristics and within-achene resource allocation in the germination strategy of tetraploid Aster pilosus var. pilosus (Asteraceae) Amer. J. Bot. 81:259-264.

Ptasznik, W. and A. A. Khan. 1993. Rctaining the benefits of matriconditioning by controlled drying of snap bean seeds. HortSci. 28:1027-1030.

Romo, J. T., R. E. Redmann, B. L. Kowalenko, and A. R. Nicholson. 1995. Growth of winterfat following defoliation in Northern Mixed Prairie of Saskatchewan. J. Range Manage. 48:240-245.

Senaratna, T. and B. D. McKersie. 1983. Dehydration injury in germinating soybean (Glycine max L. Merr.) seeds. Plant Physiol. 72:620-624.

Simpson, G. M. 1990. Seed dormancy in grasses. Cambridge Univ. Press, Cambridge.
Snedecor, G. W. and W. C. Cochran. 1980. Statistical methods. The lowa State Univ. Press, Ames, Iowa.

Springfield, H. W. 1972. Winterfat secds undergo after-ripening. J. Range Manage, 25:479-480.

Springfield, H.W. 1973. Large seeds of winterfat germinate better, J. Range Manage. 26:153-154.

Stamp, N. E. 1990. Production and effect of seed size in a grassland annual (Erodium brachycarpum, Geraniaceae). Amer. J. Bot. 77:874-882.

Stanton, J. L. 1984. Seed variation in wild radish: Effect of seed size on components of seedling and adult fitness. Ecol. 65:1105-1112.

Steiner, J.J. 1990. Seedling rate of development index: Indicator of vigor and seedling growth response. Crop Sci. 30: 1264-1271.

Venable, D. L. and J. S. Brown. 1988. The selective interactions of dispersal, dormancy, and seed size as adaptations for reducing risk in variable environments. Amer. Natur. 131:360-384.

Waddington, J. and M.C. Shoop. 1995. Influence of soil moisture on establishment of winterfat, p. 92-94. In: Abouguendia, Z. (ed.), Proc. Total ranch management in the Northern Great Plains. Grazing and Pasture Tech. Program. Saskatchewan Agric. and Food. Regina, Sask.

Young, J. A. and R. A. Evans. 1989. Dispersal and germination of big sagebrush (Artemisia tridentata) seeds. Weed Sci. 37:201-206.

Zammit, C. and P. H. Zedler. 1990. Seed yield, seed size and germination behavior in the annual Pogogyne abramsii. Oecologia 84:24-28. 